\title{
Stop Demam Berdarah Dengue (DBD) - Virtual Reality Application for Learning about Dengue Fever
}

\author{
Endah Sudarmilah, Muchamad Thoyib \\ Informatics Department, Faculty of Communication dan Informatics, University of Muhammadiyah Surakarta, Indonesia
}

\begin{abstract}
Demam Berdarah Dengue (DBD) is a disease that has a high mortality rate each year, especially in Indonesia. Improved services to this case are essential to reduce the number of dengue fever victims. However, the lack of knowledge in the community regarding dengue fever makes the efforts of eradicating this disease not optimal. Therefore, it is necessary to provide knowledge of dengue fever in the community. This study aimed to develop an android-based dengue prevention educational game application with Virtual Reality (VR) technology to provide knowledge of dengue fever to the public. This application development used the waterfall method which consisted of analysis, design, implementation, testing, and maintenance stages. Black Box Testing Method and System Usability Scale (SUS) were used as testing methods. SUS testing of 30 respondents obtained an average score of 79.4 (excellent), which means that the application was accepted by respondents.
\end{abstract}

Key words: Dengue fever, knowledge, android, virtual reality application.

\section{INTRODUCTION}

The development of science and technology has a big influence on human life. Its use is a renewal effort in various fields. Technology in the field of information is developing rapidly along with the presence of smartphones and the internet as one of the innovations in technological progress. The Indonesian Internet Service Providers Association (IISPA) states that the number of internet users in Indonesia in 2016 reached 132 million people and in 2017 there was a significant increase to 143 million people out of 262 million of the total population of Indonesia [5]. The smartphone can also provide convenience in various fields.

The use of smartphones in the health sector greatly supports services such as providing information relating to certain diseases. DBD is a disease caused by the dengue virus carried by the Aedes aegypti mosquito [7]. According to data from the Indonesian Ministry of Health [15], from the beginning of 2019 to 3 February 2019, Indonesia had 16,692 dengue cases with 169 fatalities that are spread in 34 provinces. The number was higher than the number of dengue cases at the beginning of 2018 that reached 6,167 cases [8]. The increase in dengue cases often occurs in the school environment so that prevention efforts are carried out by the school through the School's Health Clinic (SHC) which aims to maintain the health of the school environment [21]. Special attention from health agencies is essential because there are no drugs and vaccines that can overcome dengue fever.

Prevention of dengue fever such as the $3 \mathrm{M}$ program that is draining water reservoirs, covering potential places for breeding sites, and reusing used goods that have the potential to be used for breeding sites [10]. Moreover, eradication of mosquito nests (EMN) is one of the right steps in eradicating mosquitoes by involving the active role of the community. The larval free rate (LFR) is one indicator of the number of larvae in containers or the home environment. If LFR is low, it means that there is a high quantity of larvae [11]. LFR calculation is a ratio of the number of buildings that do not have larvae to the number of buildings examined multiplied by $100 \%$.

Technological developments trigger a trend of change in education from conventional methods to open education [18]. Utilization of technology with open education can provide enjoyable learning [19]. Educational games are one of the open learning models and there are learning elements that can be used ranging from desktops to smartphones [16]. Educational games have several changing trends, one of which is Virtual Reality (VR) [12]. VR is a three-dimensional (3D) drawing environment created with computer technology that looks real so it makes its users appear to be directly involved physically [20]. In addition, in 3D environments, the real form of the environment can be involved more freely. VR can be designed using a game engine to facilitate the development of various software, one of which is Unity 3D. Unity $3 \mathrm{D}$ is a software used to create games or visual content from two dimensions (2D) to 3D animation [17].

As open learning combined with VR technology can provide a pleasant knowledge, this study aimed to develop educational applications for dengue prevention education games using VR technology. The development of educational game applications was made on an Android basis because it is one of the most widely used operating systems [1]. Therefore, it was expected to provide knowledge on how to prevent dengue fever entertainingly through a smartphone.

\section{PROPOSED MODELLING}

Designing the educational game application for dengue prevention with VR technology based on Android used the waterfall model development method which consists of five stages of development, namely the analysis of device requirements, design, coding, testing, and maintenance [22]. The stages of waterfall model development are shown in Figure 1. 
Endah Sudarmilah et al., International Journal of Emerging Trends in Engineering Research, 7(11), November 2019, 441 - 448

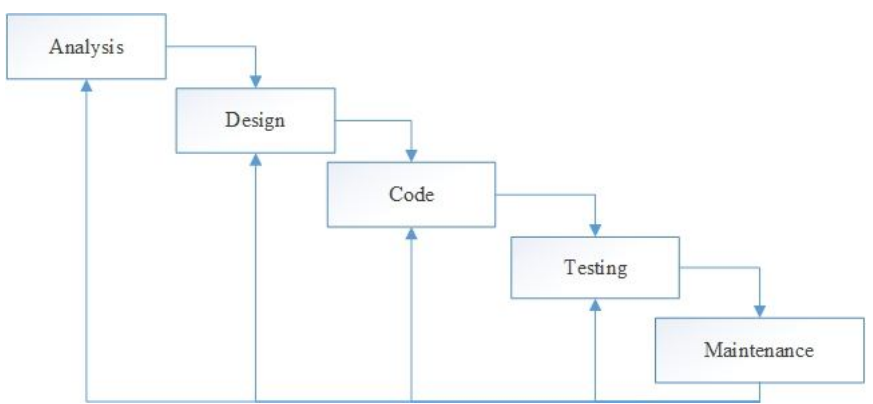

Figure 1:The Waterfall Model Development Method

\subsection{Software requirement analysis (Analysis)}

The initial stage of software design was a complete analysis of device requirements to determine the functional and nonfunctional requirements of the educational game application to be designed.

\subsubsection{Functional requirements}

Educational game application entitled "Stop Demam Berdarah Dengue (DBD) - Safe from the Danger of Dengue Fever" was an educational game using VR technology developed from a simulation game combined with an education that could only be played by a single player. This educational game was run using a joystick that functioned as the game controller. The story in this educational game was how to prevent the spread of dengue fever, which began with the search for items that could be used for breeding sites both outside and inside the house. At the final stage of the game, the $3 \mathrm{M}$ program was introduced to give an idea of how to reduce the potential for dengue mosquitoes breeding sites. The design of the educational game includes functional systems as follows.

- The application provided information on dengue fever.

- The application was equipped with videos.

- The application could interact with users.

\subsubsection{Non-functional requirements}

Non-functional requirements were the stages of the developer analyzing the resources used in designing the educational game application. The resources used in the design consisted of software and hardware.

a. Software requirement analysis

The requirements of software used to design the educational game applications were as follows.

- The operating system of Windows 10 Enterprise 64-bit

- Unity 3D

- $\quad$ Adobe Photoshop CC 2017

- Adobe After Effects CC 2018

b. Hardware requirement analysis

The hardware requirements were as follows.

- Monitor with 1366 x 768-pixel resolution.

- Intel(R) Core(TM) i3-4030U CPU @ 1.90GHz
- RAM 10 GB DDR3

- $\quad$ Storage of $500 \mathrm{~GB}$

- VGA Intel(R) HD Graphic Family 2 GB

\subsection{Design}

In this stage, the needs analysis was transformed into a form that can be understood by the user such as the description of the user interface (UI) and system activities. In addition, the design must pay attention to the qualitative and quantitative values of the game application [2]. The design of educational game design used Unified Modeling Language (UML), which is a standard language used in the design of a system [6]. UML in this educational game application includes storyboards, a use case diagram, and an activity diagram.

\subsubsection{Use Case Diagram}

A use case diagram is a diagram that illustrates actor scenarios and their relationships as sequential actions that provide interaction with actors [9]. The use case diagram of this study is shown in Figure 2.

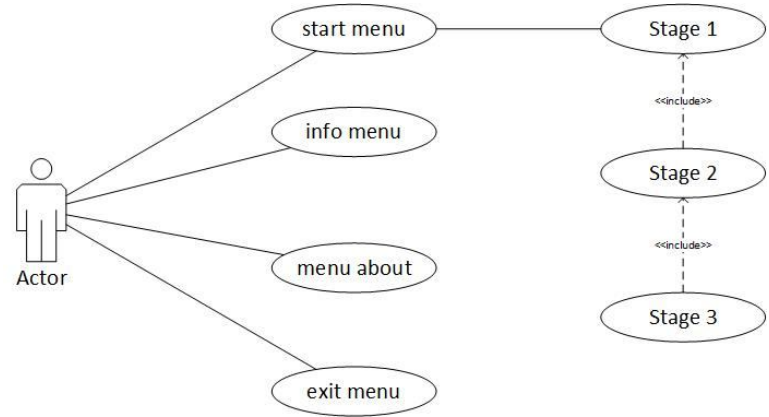

Figure 2: Use Case Diagram of the Study

\subsubsection{Activity Diagram}

An activity diagram explains the flow of software activities that illustrate the activity of software systems [9]. Activity diagrams contained in the educational game application include start menu, info menu, speech menu, and exit menu.

a. Activity diagram of the start menu

The activity diagram of the start menu used in the educational game application is shown in Figure 3.

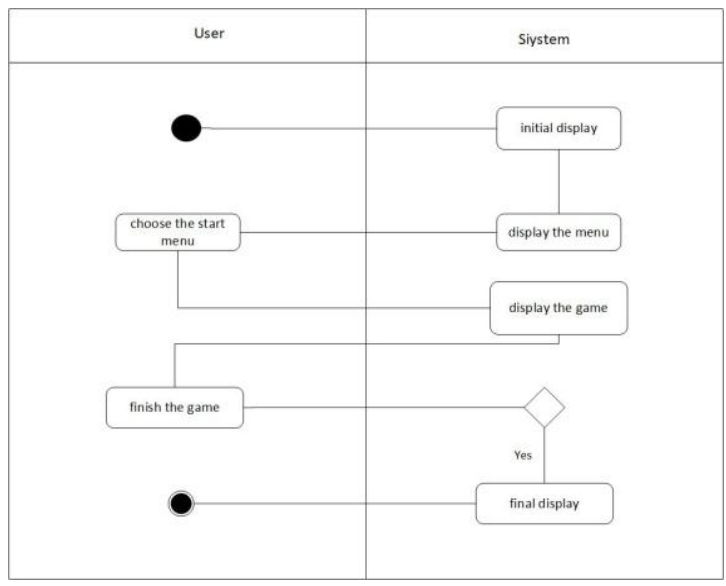

Figure 3: Activity Diagram of the Start Menu 
Endah Sudarmilah et al., International Journal of Emerging Trends in Engineering Research, 7(11), November 2019, 441 - 448

\section{Description:}

When a player opened the educational game for dengue prevention before entering the menu, there was an animated video explaining dengue fever. After entering, the player then found several menus, one of which was the start menu which was used as a play menu. On the game page, the player passed several stages before the game was finished. After finishing the game, the player can repeat it or exit it.

b. Activity diagram of the info menu

The activity diagram of the info menu is shown in Figure 4.

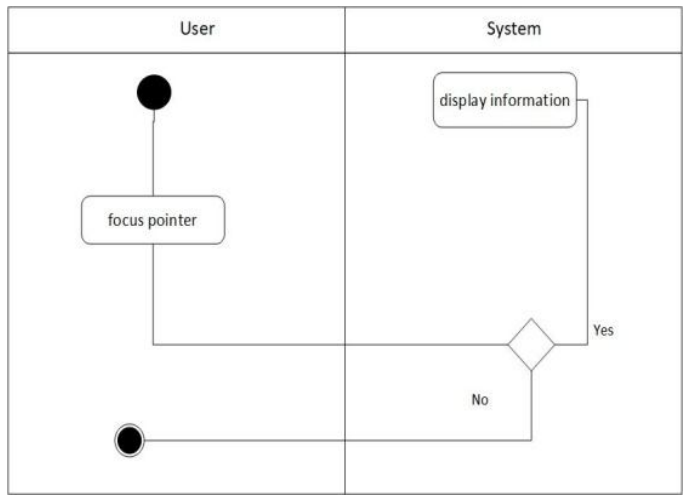

Figure 4 :Activity Diagram of the Info Menu

Description:

After the player opened the application, there was an info menu. When the player focused the pointer on the info menu, the game information would be displayed. The player could close the info menu display by not focusing the menu pointer.

c. Activity diagram of the speech menu

The activity diagram of the speech menu is displayed in Figure 5.

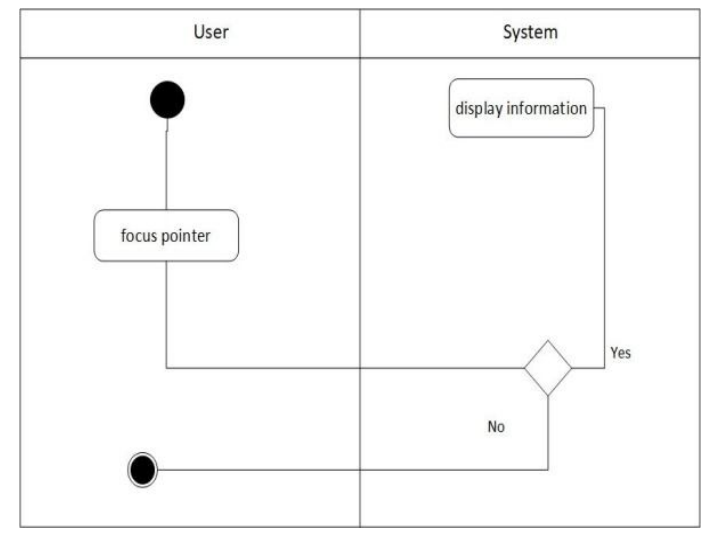

Figure 5: Activity Diagram of the Speech Menu

\section{Description:}

On the menu page, when the player focused the pointer on the speech menu, information from the researcher would appear. And if it was not focused on the greeting menu, the information would not appear.

d. Activity diagram of the exit menu

The activity diagram of the exit menu is shown in Figure 6.

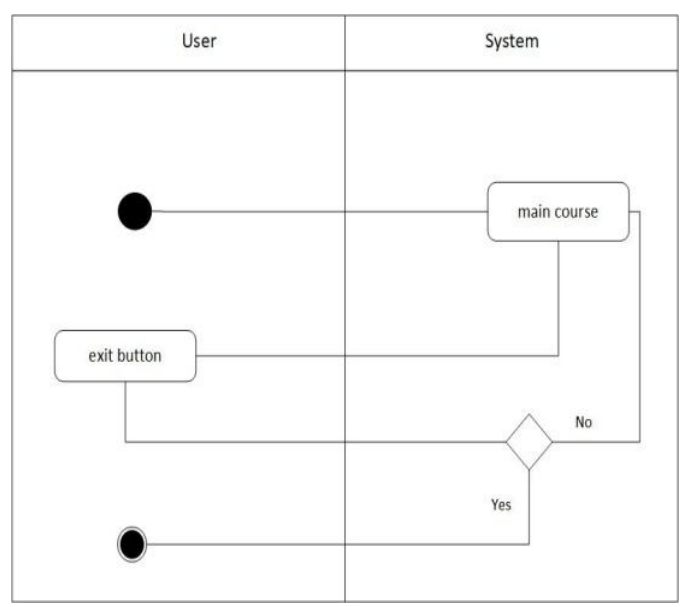

Figure 6:Activity Diagram of the Exit Menu

Description:

When the player focused the pointer on the exit menu, 2 buttons would display the information. When the pointer was focused on the "Yes" button, then the game would exit. However, when the pointer was focused on the "No" button then the information would exit and the game was continuing to run.

\section{e. Storyboard}

A storyboard is a sketch drawing arranged in order and description that contains visual and audio explanations of each plot [13]. The storyboard used of the VR application is shown in Table 1.

\subsection{Coding}

In the coding stage, the design for making interfaces was implemented and the coding of educational games with specifications according to the requirements analysis stage was done. The design goal was to develop an initial product of the educational game application by providing several functions that could be carried out by the actor. The design of educational games used Unity 3D by adding some assets that were arranged into a game environment and provided functions created with the $\mathrm{C \#}$ programming language.

\subsection{Testing}

The testing stage was carried out after the educational game was completed to evaluate the application in terms of usability, effectiveness, efficiency, and function of the application whether it could work well or not. Research testing was done using the black box testing method and the user interface testing used the System Usability Scale (SUS) model. The design of the black box testing is shown in Table 2.

\subsection{Maintenance}

The final stage of the waterfall model software development cycle in making a dengue prevention education game application was to get the public to use the developed game as a medium for the prevention of dengue fever. 
Endah Sudarmilah et al., International Journal of Emerging Trends in Engineering Research, 7(11), November 2019, 441 - 448

\section{RESULTS AND DISCUSSIONS}

This study developed an educational game application for dengue prevention with VR technology that could be played on android-based smartphones. Each development stage used the waterfall method to get its results.

\subsection{Analysis}

The analysis stage included the storyline design process, game concepts, application appearance, user identification, and needs analysis. Storyline and concept focused on the prevention of dengue fever. Application appearance was made in such a way to get an attractive 3D environment. A need analysis was used for gathering material related to the learning of dengue fever so that the objectives can be achieved. A description of the educational game application concept is shown in Table 3.

Table 1: Storyboard of the VR application

\begin{tabular}{|c|c|c|}
\hline No & Board & Keterangan \\
\hline 1 & & $\begin{array}{c}\text { The display of the start page } \\
\text { after entering the application. } \\
\text { There is a display for the game } \\
\text { intro that will show a short } \\
\text { video }\end{array}$ \\
\hline 2 & & $\begin{array}{l}\text { The display of the main menu } \\
\text { with four menus to be selected, } \\
\text { which are starting the game, } \\
\text { information regarding the game, } \\
\text { information on the game } \\
\text { developers, and exiting the } \\
\text { game. There is a background } \\
\text { sound on this page. }\end{array}$ \\
\hline 3 & & $\begin{array}{l}\text { The display shows the menu for } \\
\text { stage one of the game. In this } \\
\text { stage, the player is located } \\
\text { inside the house. to find the } \\
\text { potential places for mosquitos' } \\
\text { breeding sites. There is } \\
\text { background music on this page. } \\
\text { There is a back button to return } \\
\text { to the main menu, and the next } \\
\text { button to go to the next stage. }\end{array}$ \\
\hline 4 & & $\begin{array}{l}\text { In stage two, the player will do } \\
\text { the } 3 \mathrm{M} \text { program inside the } \\
\text { house. There is background } \\
\text { music on this page. There is a } \\
\text { back button to return to stage } \\
\text { one, and the next button to go to } \\
\text { the next stage. }\end{array}$ \\
\hline 5 & & $\begin{array}{l}\text { In stage three, the player will do } \\
\text { the } 3 \mathrm{M} \text { program outside the } \\
\text { house. There is background } \\
\text { music on this page. There is a } \\
\text { back button to return to the } \\
\text { main menu. }\end{array}$ \\
\hline
\end{tabular}

Table 2: The Design of the Black Box Testing

\begin{tabular}{|l|l|l|l|}
\hline No & Item & \multicolumn{1}{|c|}{ Scenario } & \multicolumn{1}{c|}{ Desired output } \\
\hline 1 & Start page & $\begin{array}{l}\text { Display the } \\
\text { loading } \\
\text { information }\end{array}$ & $\begin{array}{l}\text { Playing video } \\
\text { Playing sound } \\
\text { - Entering the menu } \\
\text { page }\end{array}$ \\
\hline 2 & $\begin{array}{l}\text { Main } \\
\text { menu } \\
\text { page }\end{array}$ & $\begin{array}{l}\text { Focusing pointer } \\
\text { on the start menu } \\
\text { Focusing pointer } \\
\text { on the info menu }\end{array}$ & $\begin{array}{l}\text { Displaying the main } \\
\text { page }\end{array}$ \\
$\begin{array}{l}\text { Displaying the play } \\
\text { menu }\end{array}$ \\
\hline
\end{tabular}

\begin{tabular}{|l|l|l|l|}
\hline & & $\begin{array}{l}\text { Focusing pointer } \\
\text { on the speech } \\
\text { menu } \\
\text { Focusing pointer } \\
\text { on the exit menu }\end{array}$ & $\begin{array}{l}\text { Displaying the } \\
\text { game info } \\
\text { Displaying the } \\
\text { speech info } \\
\text { Playing sound } \\
\text { Exiting the game }\end{array}$ \\
\hline 3 & $\begin{array}{l}\text { Play } \\
\text { menu }\end{array}$ & $\begin{array}{l}\text { Focusing pointer } \\
\text { to an object }\end{array}$ & $\begin{array}{l}\text { Displaying } \\
\text { information }\end{array}$ \\
\hline 4 & $\begin{array}{l}\text { The use } \\
\text { of actor }\end{array}$ & playing the game & $\begin{array}{l}\text { Being able to use } \\
\text { the controller to } \\
\text { play the game }\end{array}$ \\
\hline
\end{tabular}

Table 3: The Description of the Educational Game Application Concept

\begin{tabular}{|c|l|}
\hline Title & $\begin{array}{l}\text { Stop Demam Berdarah Dengue } \\
\text { (DBD) - Safe from the Danger of } \\
\text { Dengue Fever }\end{array}$ \\
\hline Title *.apk & STOP DBD \\
\hline $\begin{array}{c}\text { Audience } \\
\text { target }\end{array}$ & General population \\
\hline Game type & Simulation \\
\hline Platform & $\begin{array}{l}\text { Virtual reality in an android } \\
\text { smartphone }\end{array}$ \\
\hline Description & $\begin{array}{l}\text { Stop Demam Berdarah Dengue } \\
\text { (DBD) educational game application } \\
\text { provides information on the } \\
\text { prevention of dengue fever using } \\
\text { virtual reality technology in an } \\
\text { android smartphone. }\end{array}$ \\
\hline Image & $\begin{array}{l}\text { Images used were in *.jpg and *.png } \\
\text { extensions }\end{array}$ \\
\hline Audio & Audio used was in *.mp3 extension \\
\hline Video & Video used was in *.mp4 extension \\
\hline
\end{tabular}

\subsection{Design}

The design phase of this application used a storyboard to briefly describe the description of each stage. Some assets were designed to be a game environment and some $\mathrm{C} \#$ programming code performed functions in the educational game application. Animated videos and music were provided to make an educational game entertaining. The following are the results of the implementation of the educational game application for preventing dengue with virtual reality technology. The initial page of the "Stop DBD" educational game application is shown in Figure 7. 
Endah Sudarmilah et al., International Journal of Emerging Trends in Engineering Research, 7(11), November 2019, 441 - 448

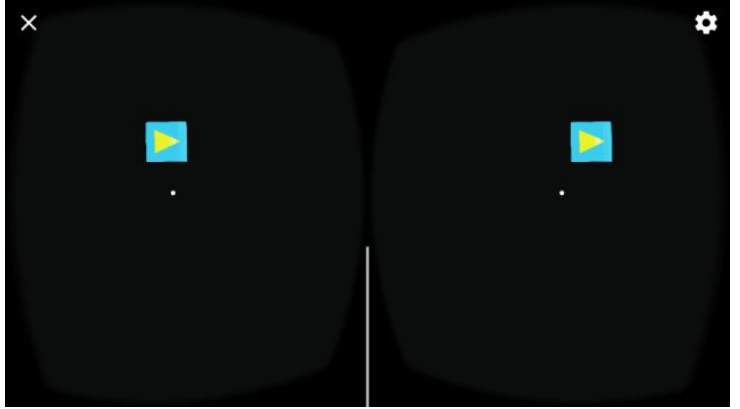

Figure 7: Start Page of the Game

After the player opened the educational game application "Stop DBD", a play button would appear to play videos of dengue fever. After the video finished, the player would automatically be directed to the main menu page to start playing. The main menu page is shown in Figure 8.

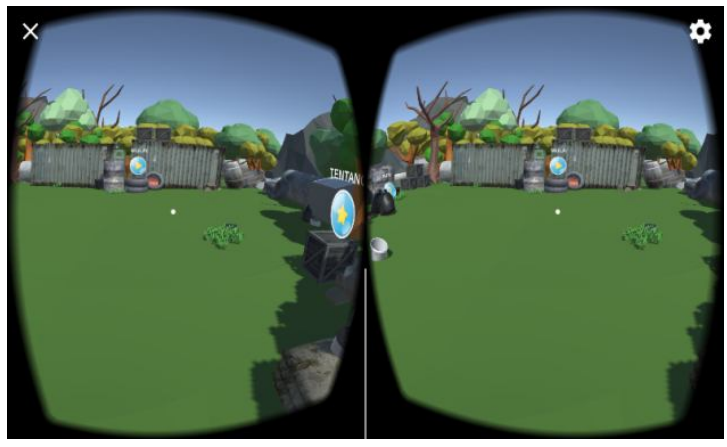

Figure 8: Display of the Play Menu

On the main menu page, the player could perform actions using a controller to move. When the player focused the pointer, then he entered the start menu as shown in Figure 9. When the player focused the pointer on the speech menu, the information would appear as shown in Figure 10.

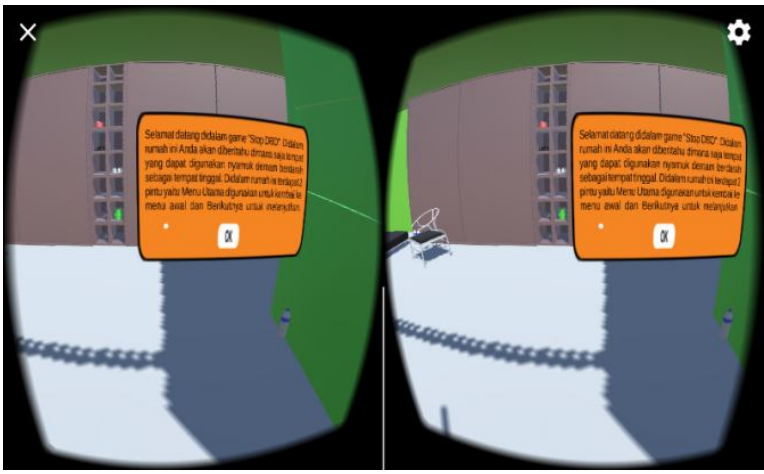

Figure 9: Start Menu Page

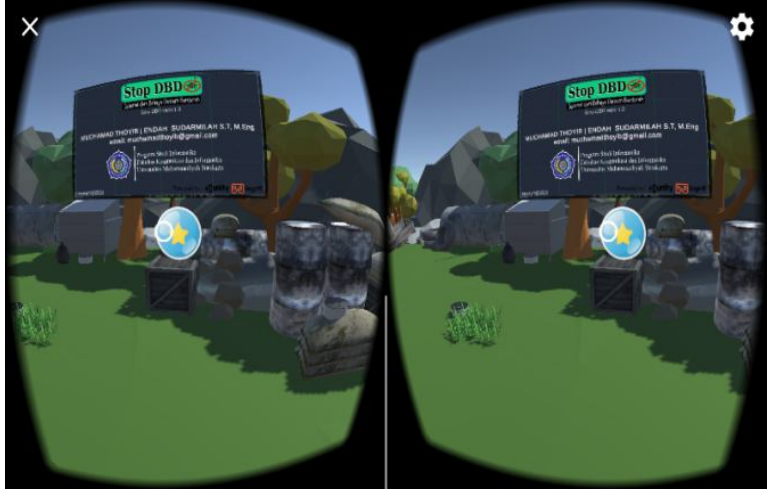

Figure 10: Display of Information On the Speech Menu

\subsection{Testing}

Testing was done to determine whether the educational game application was working effectively and efficiently using the Black Box Testing and System Usability Scale (SUS).

\subsubsection{Black Box Testing}

Black box testing can be used to determine whether the function of the application is working well or not [14]. The results of the black box testing are displayed in Table 4.

Table 4: Results of Black Box Testing

\begin{tabular}{|c|c|c|c|c|}
\hline No & Item & Scenario & Desired output & Result \\
\hline 1 & $\begin{array}{l}\text { Start } \\
\text { page }\end{array}$ & $\begin{array}{l}\text { Display } \\
\text { loading }\end{array}$ & 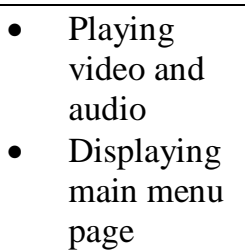 & Success \\
\hline 2 & $\begin{array}{l}\text { Main } \\
\text { menu } \\
\text { page }\end{array}$ & $\begin{array}{c}\text { Focusing } \\
\text { pointer to } \\
\text { the play } \\
\text { menu }\end{array}$ & $\begin{array}{l}\text { Displaying play } \\
\text { menu page }\end{array}$ & Success \\
\hline 3 & $\begin{array}{l}\text { Main } \\
\text { menu } \\
\text { page }\end{array}$ & $\begin{array}{c}\text { Focusing } \\
\text { pointer to } \\
\text { the info } \\
\text { menu }\end{array}$ & $\begin{array}{l}\text { Displaying pop- } \\
\text { up information }\end{array}$ & Success \\
\hline 4 & $\begin{array}{l}\text { Main } \\
\text { menu } \\
\text { page }\end{array}$ & $\begin{array}{l}\text { Focusing } \\
\text { pointer to } \\
\text { the } \\
\text { speech } \\
\text { menu }\end{array}$ & $\begin{array}{l}\text { Displaying pop- } \\
\text { up information }\end{array}$ & Success \\
\hline 5 & $\begin{array}{l}\text { Main } \\
\text { menu } \\
\text { page }\end{array}$ & $\begin{array}{c}\text { Focusing } \\
\text { pointer to } \\
\text { the exit } \\
\text { menu }\end{array}$ & $\begin{array}{l}\text { Displaying pop- } \\
\text { up with two } \\
\text { options }\end{array}$ & Success \\
\hline 6 & $\begin{array}{l}\text { Main } \\
\text { menu } \\
\text { page }\end{array}$ & $\begin{array}{l}\text { Entering } \\
\text { the menu } \\
\text { page }\end{array}$ & Playing music & Success \\
\hline 7 & $\begin{array}{l}\text { Main } \\
\text { menu }\end{array}$ & $\begin{array}{l}\text { Focusing } \\
\text { pointer to } \\
\text { options }\end{array}$ & $\begin{array}{l}\text { - 'Yes' exit } \\
\text { the game, } \\
\text { - 'No' }\end{array}$ & Success \\
\hline
\end{tabular}


Endah Sudarmilah et al., International Journal of Emerging Trends in Engineering Research, 7(11), November 2019, 441 - 448

\begin{tabular}{|c|c|c|c|c|}
\hline No & Item & Scenario & Desired output & Result \\
\hline 8 & $\begin{array}{c}\text { Play } \\
\text { page }\end{array}$ & $\begin{array}{c}\text { Focusing } \\
\text { pointer to } \\
\text { exit menu } \\
\text { an object }\end{array}$ & $\begin{array}{c}\text { Displaying } \\
\text { playing } \\
\text { information }\end{array}$ & Success \\
\hline 9 & $\begin{array}{c}\text { The } \\
\text { use } \\
\text { of } \\
\text { actor }\end{array}$ & $\begin{array}{c}\text { Playing } \\
\text { the game }\end{array}$ & $\begin{array}{c}\text { Performing } \\
\text { actions using } \\
\text { the controller }\end{array}$ & Success \\
\hline
\end{tabular}

\subsubsection{System Usability Scale (SUS)}

The testing stage used the System Usability Scale (SUS) to determine the efficiency and effectiveness of the game as well as user satisfaction of the system. SUS testing is a test on the system by giving a score [4]. SUS Testing asked 15 respondents to answer 10 items of questionnaire questions with a rating of 1 (strongly disagree) to 5 (strongly agree). Before answering the questionnaire, the respondent tried the game. The questionnaire question items were developed from a pre-arranged questions to fit the study better [3]. The questionnaire given to the respondents is shown in Table 5.

Table 5:The Questionnaire Used in The Study

\begin{tabular}{|c|c|c|c|c|c|c|}
\hline \multirow{2}{*}{ No } & \multirow{2}{*}{ Statement } & \multicolumn{5}{|c|}{ Score } \\
\hline & & 1 & 2 & 3 & 4 & 5 \\
\hline 1 & $\begin{array}{l}\text { I am thinking to play } \\
\text { this game again }\end{array}$ & & & & & \\
\hline 2 & $\begin{array}{l}\text { I think this is a } \\
\text { complicated game to be } \\
\text { played }\end{array}$ & & & & & \\
\hline 3 & $\begin{array}{l}\text { I think this is an easy } \\
\text { game to be played }\end{array}$ & & & & & \\
\hline 4 & $\begin{array}{l}\text { I need help from others } \\
\text { to use features of this } \\
\text { game }\end{array}$ & & & & & \\
\hline 5 & $\begin{array}{l}\text { I think the game } \\
\text { features work properly }\end{array}$ & & & & & \\
\hline 6 & $\begin{array}{l}\text { I think there are many } \\
\text { inconsistencies in the } \\
\text { game }\end{array}$ & & & & & \\
\hline 7 & $\begin{array}{l}\text { I think other people can } \\
\text { understand how to play } \\
\text { the game easily }\end{array}$ & & & & & \\
\hline 8 & $\begin{array}{l}\text { I think the gameplay is } \\
\text { confusing }\end{array}$ & & & & & \\
\hline 9 & $\begin{array}{l}\text { I do not feel any } \\
\text { difficulties in playing } \\
\text { the game }\end{array}$ & & & & & \\
\hline 10 & $\begin{array}{l}\text { I need to get used to the } \\
\text { instructions before }\end{array}$ & & & & & \\
\hline
\end{tabular}

\begin{tabular}{|l|l|l|l|l|l|l|}
\hline \multirow{2}{*}{ No } & \multirow{2}{*}{ Statement } & \multicolumn{5}{|c|}{ Score } \\
\cline { 3 - 7 } & & $\mathbf{1}$ & $\mathbf{2}$ & $\mathbf{3}$ & $\mathbf{4}$ & $\mathbf{5}$ \\
\hline & playing the game & & & & & \\
\hline
\end{tabular}

The final score was calculated after the respondent assessed the game. SUS scores are between 0-100 [3]. For question items numbered $1,3,5,7$, and 9, the scale contributed the score of minus 1 while for question items numbered 2, 4, 6, 8, and 10 , the scale contributed the score of minus 5 at the selected scale position [20]. For the final score, the total score then multiplied by 2.5 [3]. The SUS calculation results of respondents can be seen in Table 6 .

The total of the final SUS score (2382.5) then used to find the average SUS score using Equation (1).

$$
\text { Average }=\sum_{i=1}^{n} \frac{x_{i}}{N}
$$

$x_{i}=$ Total of final SUS score

$N=$ number of respondents

The average SUS score of this study was $\frac{2382.5}{30}=79.4$

In this section all the results and the discussions should be made.

Table 6 :The SUS Calculation Results of Respondents

\begin{tabular}{|c|c|c|c|c|c|c|c|c|c|c|c|c|}
\hline \multirow{2}{*}{ Users } & \multicolumn{10}{|c|}{ Score } & \multirow{2}{*}{ Total } & \multirow{2}{*}{$\begin{array}{c}\text { Final } \\
\text { score } \\
\text { (total* } \\
2.5 \text { ) }\end{array}$} \\
\hline & 1 & 2 & 3 & 4 & 5 & 6 & 7 & 8 & 9 & 10 & & \\
\hline 1 & 3 & 2 & 4 & 3 & 5 & 1 & 3 & 2 & 4 & 3 & 30 & 75 \\
\hline 2 & 5 & 2 & 5 & 2 & 4 & 3 & 4 & 2 & 4 & 4 & 35 & 87.5 \\
\hline 3 & 4 & 2 & 5 & 4 & 4 & 1 & 3 & 2 & 4 & 4 & 33 & 82.5 \\
\hline 4 & 5 & 1 & 4 & 2 & 5 & 2 & 4 & 1 & 4 & 4 & 32 & 80 \\
\hline 5 & 5 & 1 & 5 & 2 & 5 & 2 & 4 & 1 & 4 & 3 & 32 & 80 \\
\hline 6 & 4 & 1 & 4 & 1 & 5 & 1 & 4 & 1 & 5 & 2 & 28 & 70 \\
\hline 7 & 3 & 1 & 5 & 1 & 4 & 3 & 2 & 1 & 5 & 2 & 27 & 67.5 \\
\hline 8 & 4 & 2 & 4 & 2 & 1 & 2 & 4 & 3 & 5 & 5 & 32 & 80 \\
\hline 9 & 4 & 1 & 5 & 2 & 5 & 2 & 4 & 2 & 4 & 4 & 33 & 82.5 \\
\hline 10 & 4 & 2 & 3 & 2 & 4 & 2 & 4 & 2 & 4 & 2 & 29 & 72.5 \\
\hline 11 & 5 & 2 & 5 & 1 & 4 & 2 & 5 & 2 & 5 & 2 & 33 & 82.5 \\
\hline 12 & 4 & 2 & 3 & 2 & 4 & 2 & 3 & 2 & 4 & 2 & 28 & 70 \\
\hline 13 & 4 & 2 & 4 & 2 & 4 & 2 & 5 & 2 & 4 & 4 & 33 & 82.5 \\
\hline 14 & 4 & 2 & 4 & 2 & 5 & 2 & 4 & 2 & 5 & 4 & 34 & 85 \\
\hline 15 & 4 & 2 & 4 & 2 & 5 & 2 & 2 & 1 & 4 & 4 & 30 & 75 \\
\hline 16 & 2 & 3 & 4 & 4 & 5 & 3 & 5 & 4 & 3 & 4 & 37 & 92.5 \\
\hline 17 & 4 & 4 & 5 & 5 & 4 & 2 & 4 & 2 & 4 & 4 & 38 & 95 \\
\hline 18 & 3 & 2 & 4 & 2 & 4 & 2 & 5 & 2 & 4 & 4 & 32 & 80 \\
\hline
\end{tabular}


Endah Sudarmilah et al., International Journal of Emerging Trends in Engineering Research, 7(11), November 2019, 441 - 448

\begin{tabular}{|c|c|c|c|c|c|c|c|c|c|c|c|c|}
\hline \multirow{2}{*}{ Users } & \multicolumn{10}{|c|}{ Score } & \multirow{2}{*}{ Total } & \multirow{2}{*}{$\begin{array}{c}\text { Final } \\
\text { score } \\
\text { (total* } \\
2.5 \text { ) }\end{array}$} \\
\hline & 1 & 2 & 3 & 4 & 5 & 6 & 7 & 8 & 9 & 10 & & \\
\hline 19 & 4 & 5 & 4 & 4 & 5 & 2 & 5 & 2 & 5 & 4 & 40 & 100 \\
\hline 20 & 4 & 5 & 3 & 4 & 5 & 4 & 2 & 4 & 2 & 4 & 37 & 92.5 \\
\hline 21 & 4 & 2 & 5 & 4 & 5 & 2 & 5 & 2 & 5 & 4 & 38 & 95 \\
\hline 22 & 3 & 2 & 4 & 2 & 4 & 2 & 4 & 2 & 4 & 4 & 31 & 77.5 \\
\hline 23 & 2 & 4 & 2 & 1 & 2 & 4 & 4 & 2 & 5 & 4 & 30 & 75 \\
\hline 24 & 4 & 2 & 1 & 2 & 1 & 2 & 1 & 2 & 1 & 2 & 18 & 45 \\
\hline 25 & 4 & 2 & 4 & 4 & 4 & 2 & 4 & 1 & 4 & 1 & 30 & 75 \\
\hline 26 & 4 & 3 & 3 & 4 & 4 & 4 & 3 & 3 & 2 & 4 & 34 & 85 \\
\hline 27 & 3 & 2 & 4 & 1 & 4 & 2 & 4 & 1 & 4 & 1 & 26 & 65 \\
\hline 28 & 5 & 1 & 4 & 2 & 5 & 1 & 4 & 1 & 5 & 2 & 30 & 75 \\
\hline 29 & 4 & 2 & 4 & 4 & 4 & 2 & 3 & 2 & 4 & 2 & 31 & 77.5 \\
\hline 30 & 4 & 2 & 4 & 2 & 5 & 2 & 4 & 2 & 4 & 3 & 32 & 80 \\
\hline & & & & & & & & & & & & 2382,5 \\
\hline
\end{tabular}

The average SUS score is a benchmark of how well the game performs according to the respondents. The educational game application for the prevention of dengue with Android-based VR technology was accepted by the respondents with an average SUS score of 79.4. Based on the SUS score ranking as shown in Figure 11, the developed game was in the excellent category [4].

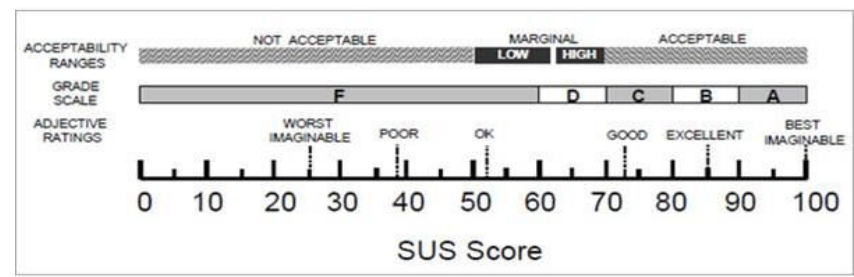

Figure 11: SUS Score Ranking

\section{CONCLUSION}

Dengue fever educational game application with Androidbased VR technology was developed to provide information on dengue fever. Based on the black box testing results, the educational game application worked properly. This educational game provided information on dengue fever including the introduction of potential places for mosquitos' breeding sites as well as providing knowledge of the application of 3M programs indoors and outdoors. In the SUS testing, the educational game application obtained an average score of 79.4, which was in the excellent category.

\section{REFERENCES}

[1] Africa, A. D. M., Ching, G., Go, K., Evidente, R., \& Uy, J. (2019). International Journal of Emerging Trends in Engineering Research A Comprehensive Study on Application Development Software Systems. International Journal of Emerging Trend in Engineering
Research, 7(8).

https://doi.org/10.30534/ijeter/2019/03782019

[2] Bhanu, D. J. S., Sastry, D. J., Devi, B. S., \& Prakash, D. V. C. (2019). of Emerging Trends J . Sasi Bhanu International Career Guidance through TIC-TAC-TOE Game. International Journal of Emerging Trends in Engineering Research, 7(6). https://doi.org/10.30534/ijeter/2019/01762019

[3] Brooke, J. (1996). SUS-A quick and dirty usability scale. Usability evaluation in industry, 189(194), 4-7.

[4] Brooke, J. (2006). A Retrospective. The Physiologist, 49(3), 171-173.

[5] C, A. S. C. R. E., Noventius, C., \& W, A. B. (2018). Media Interaktif Virtual Reality Biota Laut Indonesia Sebagai Media Pembelajaran Untuk Usia 11-13 Tahun.

[6] Dharwiyanti, S., \& Wahono, R. S. (2003). Pengantar Unified Modelling Language(UML), 1-13.

[7] Fidayanto, R., Susanto, H., Yohanan, A., \& Yudhastuti, R. (2013). Control Model of Dengue Hemorrhagic Fever. Jurnal Kesehatan Masyarakat Nasional, 7(11). https://doi.org/10.21109/kesmas.v7i11.366

[8] Fithri, D. L., \& Setiawan, D. A. (2017). Analisa Dan Perancangan Game Edukasi Sebagai Motivasi Belajar Untuk Anak Usia Dini. Simetris: Jurnal Teknik Mesin, Elektro dan Ilmu Komputer, 8(1), 225-230. https://doi.org/10.24176/simet.v8i1.959

[9] Haviluddin. (2011). Memahami Penggunaan UML (Unified Modelling Language). Jurnal Informatika Mulawarman Vol 6 No. 1 Febuari 2011 1, 6(1), 1-15.

[10] Kemenkes RI. (2016). Kendalikan DBD Dengan PSN 3M Plus. Kementerian Kesehatan Republik Indonesia, 2-3. Diambil dari http://www.depkes.go.id/article/view/16020900002/kend alikan-dbd-dengan-psn-3m-plus.html

[11] Muhson, A. (2010). Pengembangan Media Pembelajaran Berbasis Teknologi Informasi. Jurnal Pendidikan Akuntansi Indonesia, https://doi.org/10.21831/jpai.v8i2.949

[12]Newman, D. (2017). Top 6 Digital Transformation Trends In Automotive Industry. Forbes.

[13] Nurhasanah, Y. I., \& Destyany, S. (2016). Implementasi Model CMIFED Pada Multimedia Interaktif Untuk Pembelajaran Anak Usia TK Dan Playgroup. Jurnal Informatika, Vol. 2(2), 12.

[14]Pressman, R. S. (1983). Software engineering: A practitioner's approach. Advances in Engineering Software (1978), 5(3), 171. https://doi.org/10.1016/01411195(83)90118-3

[15]Pusdatin Kemenkes RI. (2017). InfoDatin Demam Berdarah Dengue 2017. Diambil dari http://www.pusdatin.kemkes.go.id/download.php?file=do wnload/pusdatin/infodatin/InfoDatin-Situasi-DemamBerdarah-Dengue.pdf

[16] Rahman, A. Z., Hidayat, T. N., \& Yanuttama, I. (2017). Media Pembelajaran Ipa Kelas 3 Sekolah Dasar Menggunakan Teknologi Augmented Reality Berbasis Android. Seminar Nasional Teknologi Informasi dan Multimedia, 5(1), 4-6-43. Diambil dari http://ojs.amikom.ac.id/index.php/semnasteknomedia/arti cle/view/1797 
Endah Sudarmilah et al., International Journal of Emerging Trends in Engineering Research, 7(11), November 2019, 441 - 448

[17]Randi, A. (2017). Pemanfaatan Teknologi Virtual Reality Sebagai Media Pembelakaran Interaktif Untuk Sistem Tata Surya Berbasis Android.

[18] Shalikhah, N. D., Primadewi, A., \& Iman, M. S. (2018). Media Pembelajaran Interaktif Berbantu Software Lectora inspire. Desimal: Jurnal Matematika, 1(2), 237. https://doi.org/10.24042/djm.v1i2.2583

[19] Sudarmilah, E., Ferdiana, R., Nugroho, L. E., Susanto, A., \& Ramdhani, N. (2013). Tech review: Game platform for upgrading counting ability on preschool children. Proceedings - 2013 International Conference on Information Technology and Electrical Engineering: "Intelligent and Green Technologies for Sustainable Development”, ICITEE 2013, (October), 226-231. https://doi.org/10.1109/ICITEED.2013.6676243

[20] Sudarmilah, E., \& Siregar, R. M. P. (2019). The usability of "keepin" collect the trash: Virtual reality educational game in android smartphone for children. International Journal of Engineering and Advanced Technology, 8(4), 944-947.

[21] Sumardani, D., Midaraeni, I., \& Sumardani, N. I. (2019). Virtual Reality Sebagai Media Pembelajaran Relativitas Khusus Berbasis Google Cardboard Pada Smartphone Android. Prosiding Seminar Nasional Pendidikan KALUNI, 2, 309-321. https://doi.org/10.30998/prokaluni.v2i0.80

[22] Suryadi, A. (2018). Perancangan Aplikasi Game Edukasi Menggunakan Model Waterfall. Jurnal Petik, 3(1), 8. https://doi.org/10.31980/jpetik.v3i1.352 